Nikita RAVOCHKIN

\title{
HISTORY OF IDEAS ROLE IN IMPLEMENTING MODERN CRISES
}

\begin{abstract}
The history of ideas is a relatively new concept, which has not only the theoretical inherent in it but also in the spirit of modernity is able to reveal its own applied potential. The article shows the role of the history of ideas in the search for answers to the crises of the modern world, which makes it possible to establish some regularities in the functioning of intellectual constructs and their social embodiment. The author examines the basic provisions of the research concepts of the adherents of the history of ideas A. Lovejoy and I. Berlin. Using the conceptual foundations of their theories, the author applies them to a deeper understanding of the specifics of such megatrends as the COVID-19 pandemic, armed conflicts and information wars. It was revealed that the specificity of the global world transforms the content of events that traditionally affect one sphere and now spread to various spheres of the nonlinear and fragile world. In conclusion, the author sums up the research results and notes the methodological possibilities of the history of ideas for further study of the logic of social processes.
\end{abstract}

Keywords: ideas, history of ideas, society, crises, modern world, globalization.

\section{Introduction}

Of course, we can agree with those who believe that philosophy is concerned with the study of thinking and its evolution. Therefore, she cannot lose sight of the very results of the activities of various intellectuals, the limiting content of which about something is fixed in the category of "idea". As a rule, in the process of comprehending various objects, new ideas arise that are most directly related to the comprehension of the essence and ways of realizing these objects. Absolutely all great ideas always have their own destiny: some quickly find universal responses, while some have to struggle to make their way. We believe that each of the researchers of the social at least once wondered why people recognize the a priori correctness of some seemingly hopeless ideas and at the same time show scepticism about the content of other intellectual constructs that have become the result of longer reflections. The applied nature of modern social philosophy seems to be a significant understanding of how intellectual ideas can be interpreted and applied in practice in social, political, cultural and other reality. Thus, a critical analysis of research concepts to determine the vectors of using their provisions in order to solve certain social problems explains the relevance and significance of this study.

History of Ideas:

Theoretical and Applied Aspect

Determination of opportunities for the applied use of the provisions of certain concepts 
predetermines some initial theory, which places intellectual constructs at the centre of its research. One of these is Arthur Onken Lovejoy's "history of ideas" project, for which ideas have not only broad but sometimes extended content. In his book "The Great Chain of Being", Lovejoy (1936) forms the idea of the intellectual history of mankind as a set of separate teachings and systems, each of which has its own historical and cultural significance. The rationale for this thesis lies on the surface: the ideological inspirers and mentors of the American philosopher were pragmatists and evolutionists, whose research methodology was largely reflected in the demands made to modern philosophy.

Indeed, today it is pragmatic foundations, as opposed to abstraction and abstractness, that are becoming the determining principle of the viability of concrete ideas. As forms of human intellectual activity in the contexts of certain historical periods and societies, ideas, in their own way, depending on understanding, interpretation and application, set the principles of explaining and constructing the world: "Behind any private intellectual and philosophical ideas, there is a phenomenon or several phenomena that are elementary, basic and deeper than any general idea" (Hludneva, 2003). From the presented logic, it follows that any established conceptual system is a consequence of the development of a common ongoing and socio-culturally predetermined history, significantly affecting the development of social processes. In this regard, as Lovejoy himself rightly asserts, along with the variety of ideas existing at a certain interval, the search for common foundations acquires value, allowing theoretical concepts to form and, after that, to solve urgent social problems at a practical level. According to the history of ideas, all theoretical concepts can be interpreted as events that oc- curred in the intellectual life of a particular society or all of humanity.

In this case, the category "event" is interpreted in a postmodern sense since its content expresses a certain essence of specific social phenomena. Since the modern social system is developing at a rather rapid pace, the events themselves, as forms of preserving the content of the meanings prescribed to social phenomena, are transformed along with the nonlinearity of the processes taking place. Postmodernity makes it possible to identify events and concepts that reveal "real events of social life, identical to this concept" (Pilyugina, 2014). It is along this trajectory that the so-called "philosophy of the event" takes shape, where the world and society are considered as a set of actions and should be understood exclusively as the end result of concrete development in certain existing conditions. Alain Badiou is a prominent representative of this search. In his philosophy, the world is thought of as a plurality, in which thought exists in conditions of polymorphism and pluralism, and it is for this reason that it is difficult to find any universal foundation in society (Badiou, 2014).

We dare to assume that from now on, an unambiguous definition of an event with the help of reason and clear cause-and-effect relationships is losing its relevance because now other ways of denoting social facts are being implemented. E. V. Pilyugina (2014) summarizes that in Badiou's reasoning about the ways of comprehending an event, the following forms can be distinguished:

1. Mathema (direct rational naming, naming an event);

2. Poem (contextual name, reduction to common images);

3. "Invented policy" (the name of an event that is exploited by the authorities);

4. Thoughts about love (exploitation of the 
basic sexual instinct).

As a result of the breakdown of the relationship between these options, it becomes possible to provide descriptions of any event with almost any meaning. For example, the event of power can be portrayed as thoughts of love (scandals around the private life of the political establishment) or through poetics through the glorification of specific heads of state (Badiou, 2014).

We see that the philosophy of events opens up a wide range of possibilities for describing modern society and the interactions taking place in it. In a similar way, Lovejoy proposed analyzing the formation of the history of intellectual ideas. In this case, it is always necessary to pay attention not only to the totality of rational ways of signifying but mainly to analyze the conditions due to which specific phenomena received certain meanings (Hludneva, 2005). So there are options for explaining topical social processes and identifying the reasons that contribute to their emergence, and understanding the principle of functioning. In this sense, any intellectual scheme, regardless of the coordinates of the historical era and the conditions of its emergence, becomes applicable to the modern world.

When forming the conceptual foundations of any worldview, the so-called "ideas-units" become basic, to which Lovejoy (1936) refers:

1. Implicit preferences as more or less unconscious habits that determine the mental activity of entire generations;

2. Nodal intellectual constructions of a specific community or individual subjects;

3. Thoughts expressing an emotional attitude;

4. Historically defined teachings formed on specific historical periods;

5. Hypotheses reflecting hope for a definite future.

The presented concepts underpin the ideo- logical foundations of the individual, networks of intellectuals, and in potency can reach the level of the whole society and the world, setting the basic principles of action for a relatively long period. Indeed, today in various intellectual systems, one can find a huge number of confirming examples: philosophy, religion, ideology, the humanities and social sciences, where unit ideas can migrate an infinite number of times from one phenomenon to another, transforming its content in a natural way. A separate example of the implementation of the presented concept is the thesis that Plato's basic ideas about abundance, having passed through the centuries, significantly influenced not only the history of philosophy of the Western world but also largely predetermined its modern appearance (Zhuravleva, 2013). And such examples of ideas can be found in absolutely any cultural era and philosophical tradition: G. V. Leibniz predetermined phenomenology from E. Husserl to the present day. For this reason, the leading meaning of activities for the study and practical application of ideas (but not in their pure form, but only, as follows from the theory of interpretation, their modifications) can be formulated as follows: search and selection of basic intellectual products with the subsequent highlighting of provisions and testing of their applications in a specific area depending on the degree of congruence.

Close in spirit to Lovejoy are the views of the British thinker I. Berlin, for whom the basic position of intellectual history is ideological pluralism, in accordance with which people choose the priority principles for implementing actions from the "menu of intellectual constructs" strictly based on the current context. On the basis of this, a subjectivist understanding is formed not only of the value world but also of the historical process, which allows one to fully express and 
take into account all the wealth of ideas available and associated with certain spheres of human existence (Berlin, 2001).

According to Berlin, this principle allows activism to be manifested as the main essence of a person, determining the ability of each individual to form his own unique living world. Undoubtedly, this approach is largely close to the maxims of existential philosophy, but Berlin manages to translate the idea of activism further and wider mainly through statements about the competitive nature of intellectual history, which is a space of confrontation of ideas, the nature of which is rooted in the very essence and functioning of mental activity. The so-called "radical choice", that is, "carried out without rational guidelines that guarantee the "right" choice, or justify the wrong one, is of paramount importance here" (Granovskaya, 2015).

Berlin's (2001) thesis of radical pluralism is extrapolated to the levels of ethics, values and cultural forms, which highlights the applied possibilities of using ideas in relation to any social. And if the ethical and value levels of radical pluralism find a predominantly individual manifestation, thereby allowing each person to express themselves and come to the most comfortable form of their existence, then the cultural level is able to lay conceptual foundations that determine the possibilities for the deployment of transformation processes. The presented provisions apply not only to individuals who actively produce ideas or are active in a specific area but also to entire groups, communities and civilizations, defining the institutionalization of the main characteristics of social interactions.

\section{Ongoing Debate about COVID-19}

The analysis of the views of prominent the- oreticians of the considered direction of intellectual searches provides a rich toolkit for considering the ideological content of current social processes. Considering that intelligence is becoming the most demanded resource that determines the general evolutionary scenario of development, we believe that in moments of crisis for the existence of the world society, ideas acquire decisive importance for relevant and timely responses to the challenges and threats facing states. It is important to take into account the unequal nature of the manifestation of these negative markers, depending on socio-cultural and historical conditions, and even with reference to specific geographic coordinates in which the (macro) regions are localized.

Let's consider several topical megatrends of the modern world, which have really become large-scale in their coverage of the global society and require timely and unique responses to resolve current difficulties and minimize destructive consequences. One of these manifestations, which seemed at the very beginning of its manifestation to be an insignificant event, is the Covid-19 (SARS-COV-2) coronavirus pandemic, which has swept the whole world to this day. In the special medical literature, it is noted that the aetiology and epidemiology of this virus are associated with a group of coronaviruses, among which by the end of 2019, there were already four varieties that led to the emergence of acute respiratory viral infections, damaged the upper respiratory tract and did not differ clinically from other acute respiratory viral infections. Numerous studies have shown that SARS-COV-2 originated from the bat coronavirus, but its "intermediate host" has not yet been identified (Shamsheva, 2020). During the pandemic, the coronavirus has demonstrated that it can quickly transmit from person to person and spread between 
states, regardless of the preventive measures taken. It was the speed at which the new coronavirus spread, as well as the suddenness of its scenarios, that led the World Health Organization to declare a public health emergency of international concern.

The SARS-COV-2 virus is new and turns out to be quite dangerous for human life in conjunction with concomitant diseases: "The category of high mortality risk from COVID-2019 should include elderly patients with concomitant diseases, especially with damage to the cardiovascular system" (Romanov, 2020). However, this one does not at all contribute to calm and balanced reactions in the search for answers. In the context of the transparency of the world, it is not only and not so much about SARS-COV-2 itself, but about its informational and political descriptions, as well as in connection with the number and polarity of its assessments in conjunction with the rapid transformations of the worldview.

The essence of the political and information megatrend called COVID-2019 is that, from the point of view of the medical expert community, the virus is far from the most dangerous among others, both in historical retrospect and in modern society. A. Gromyko notes that in the history of the 20th century, not to mention earlier periods, there were viruses that were much more dangerous to human health and life. In particular, he cites statistics that by 2019 HIV alone had claimed more than 30 million lives, but at the same time, the world community is relatively calm, having come to terms with the idea of its incurability (Gromyko, 2020).

The most significant in the discussions around COVID-2019 is the presence of controversial and mutually exclusive points of view about its origin, distribution and consequences. It seems problematic that such controversies have an extremely difficult impact on the popular mindset. It can be seen with the naked eye that in terms of the effect of its multidirectional impact, the new coronavirus has actually left behind the scale of the global world. The main reasons are the instantaneous spread of the disease and the ideological struggle of various political structures that unfolded in the transformed media space.

Today, mass media technologies make it possible to spread information extremely quickly, changing the plastic and very sensitive consciousness of a modern person. We agree with Gromyko that the COVID-2019 pandemic "demonstrates the vulnerability, if not the illusion of freedom of movement as a given. Having got used to it, people were not prepared for the side effects of this freedom. The question arises whether the realization will come that freedom to live in a world without major wars and freedom of movement, like all other freedoms, are not absolute and not guaranteed to us from birth, but are conditioned by the behaviour and actions of each new generation of people" (Gromyko, 2020). Indeed, one might wonder if this state of affairs might not change relations between states, not to mention the status of human rights and freedom of movement?

We observe how rapidly the role of national states is changing, which has conditioned the vital nature of the need to establish partnerships with supranational institutions, not only not allowing but also not suggesting an antagonistic scenario for the development of events in the near future. The issue of the need to mobilize resources to combat the pandemic is quite acute in the world. It is reflected in the functions assigned to the executive authorities and special services, which in the vast majority of countries have already acquired additional powers and formed additional instruments of coercion. In 
this regard, it is important to note the sceptical sentiments of researchers and citizens, who are directed to the fact that the powers and instruments of coercion obtained in a state of emergency will remain with the relevant services forever. Such ideas of critical political realism reflect the facts that if at the medical level the pandemic can recede, then at the political level, it will not go anywhere, which will manifest itself in maintaining a high degree of control over society.

Based on the above, the essence of the COVID-2019 megatrend can be formulated in several positions:

- Inversion of the "balance of power" prevailing in the global world, contributing to an increase in the role of national states and executive authorities;

- The multivariate nature of achieving the desired goals as a natural reaction to a single threat: the political establishment seeks to simultaneously reformat the economy, regional politics, law, culture, demography.

- Practical implementation of a new phase of the information war: the pandemic is becoming a propaganda tool and reveals the essential characteristics of ideology, first of all, double standards and discrediting opponents.

The megatrends of the modern world, which include COVID-2019, tend to go beyond the only sphere of their objectification (in this case, medicine), producing complex fluctuations and requiring multidimensional planning of responses. A distinctive feature of such events is the instability of the still unformed world-system, in which the usual institutions are destroyed, and there is simply no time left for effective transformations and adjustments of mechanisms since the conditions of new challenges and threats are imposed on the resolved problems (Shumilin, 2020). Global informatization leads to the fact that rumours and the Internet as the most accessible and understandable tools of mass use fall into the category of reliable sources, along with official information (Sadykov \& Ahmetyanova, 2020). It is thanks to the intersections of technological innovation and the intellectual culture of the mass consumer, prevailing in many countries, that uncritical anchorage of information labelled as "true", and "reliable" is provided, which interferes with the selection and transmission of important data.

\section{War Faces in the $21^{\text {st }}$ Century}

Another megatrend is associated with transformations in the nature and methods of warfare. First of all, the formation of this megatrend is associated with the reluctance of modern states to wage regional or world wars. An indicative illustration of what has been said is the following opinion: "The prevailing idea of the modern military policy of the American state is the transition from the idea of mutually assured destruction in the course of a war with available nuclear weapons to the idea of guaranteed destruction of the enemy" (Radikov, 2015). The interconnectedness and nonlinearity with the simultaneous fragility of modern realities make it possible to assert that modern states are no longer guided by the war of global destruction of mankind as the crudest form of political influence on other states and entire regions since their political establishment itself realizes the riskiness of its own existence. Today countries form their offensive and defensive policies based on the desire to narrow their interests, as a result of which "local wars" are spreading.

So, if in the modern world it is possible to 
talk about the conduct of hostilities, then they acquire the framework of very limited territory, making the war insignificant in terms of informational effect, but a rather promising event in terms of benefits and results from the standpoint of the participants. The factors influencing the formation of local wars include minor internal troubles over the uneven distribution of monetary resources or legislative initiatives of subjects seeking to retain power for as long as possible through new legal norms. By the way, this also includes the importance of intellectual influence from the outside, perceived by influential actors as an advanced experience of state-building, as a result of which war is seen as a necessary condition for achieving social success. The analysis of the events of modern events is rich in examples of the so-called "asymmetric" wars when one of the parties (most often the attacking one) of a military conflict turns out to be much stronger in terms of numbers and technological equipment than the other side of the conflict (the defenders).

One of the forms of manifestation of this type of military clashes is the use by the aggressor countries of the entire arsenal of technological capabilities to accelerate hostilities. These changes in the nature of armed conflicts are manifested in the formation of two asymmetries (1) strength and (2) weakness (Myunkleg, 2003). In practice, stronger states seek to end the war as soon as possible in order to minimize their own costs, while a weaker participant seeks to drag out hostilities for a longer period to voice any territorial or other preferences that are the personal interests of specific actors than the entire state.

In addition, the status of national states as participants in military conflicts is changing. If earlier the war was seen as a matter exclusively of the state, since it was it who could afford to quickly mobilize resources to protect or conquer resources, then in the $21^{\text {st }}$-century, conflicts are waged with the involvement of other actors, one of which is private military companies. Some researchers rightly show that in the modern world, states have lost their monopoly on the conduct of hostilities, and in their place have come ethnic or religious communities and even entire national organizations. A significant reduction in the cost of weapons itself, as well as the actual absence of costs for training the army, are mentioned as the reasons. As a result, the war is not only a confrontation between the state against the state but, to a greater extent, a commercial project (Afanasyev, 2014). It is selfevident that the ideas underlying the megatrend of the transformation of the essence and forms of warfare are rooted in the already mentioned multidimensionality, when "local" political claims correspond to the economy, culture and the sphere of spiritual production.

A correlate to military action is information warfare as another megatrend of our time. As a form of interaction between various subjects, information warfare has acquired a special scope and specific value in the modern world. Refusal to wage global wars in favour of local states, in the event of an initiative to unleash wars, are forced to somehow explain and substantiate the motives of their aggressive behaviour and the need for the presence of a contingent of troops in a particular region or state.

Various scientific developments note that information warfare as a form of influence on the enemy is an ancient invention, but the modern format of this type of war is that they become a kind of replacement for the usual "hot" wars. The transformation of information wars took place mainly due to the use of modern technical and electronic means to solve the assigned tasks 
related to inflicting damage in order to weaken opponents or destroy them (Kibardin, Denisenko, \& Saruhanyan, 2015).

The particular importance of waging information wars is that in the modern world community, they allow not only supplementing but also consolidating the success of military operations. The victory in the information war makes the influence of one state on another more effective. We can say that the paradigm of modern information warfare by developed countries is to oppose scientific and technological revolutions to socio-political ones. It is in this logic that the strengthening of the countries of the world "core" takes place, receiving the best resources from the states of the semi-periphery and periphery (Sinchuk, 2018).

In this regard, one cannot but mention the transformations of the technologies of conducting and the direction of information wars. By and large, weak countries have nothing to oppose due to the backwardness of technical and technological equipment, which predetermines the unidirectional nature of the spread of information flows. The method of "colour" revolutions, implemented in the countries of the former Soviet Union and a number of other states, is becoming a new method of influence. This technology offers numerous (from successful to failure) options for adapting liberal-democratic ideas to the national context with the replacement of the government regime (Sinchuk, 2017). For the most part, modern information wars are associated with ideological collisions between states.

Thus, the ideological foundations of this megatrend are the possibilities of using the technical and technological level of modern culture and civilization used to deliver the necessary information and apply a set of methods of intellectual influence on certain groups. The result of this use of the technical side of modern society is the consolidation of the success of practical actions in the worldview, ideology and public opinion of a particular society. Part of the idea of information warfare is that it is a means of replacing classical warfare in order to achieve the desired results.

\section{Conclusion}

Absolutely all great ideas always have their own destiny: some quickly find universal responses, while some have to struggle to make their way. We believe that each of the researchers of the social philosophy at least once wondered why people recognize the a priori correctness of some seemingly hopeless ideas and at the same time show scepticism about the content of other intellectual constructs that have become the result of longer reflections.

In general, we see that the history of ideas, within the framework of which the significance of historically determined grounds for the formation of specific concepts and actions based on them, is recognized is quite effective in describing modern processes. In many ways, Lovejoy was right in noting that great ideas are possible not only in philosophy. We see the main difference in the ideas produced by representatives of various research directions in the connections established in these intellectual constructs from the appropriate angle of view and the scope of application of these results. Representatives of the history of ideas pay attention to the importance of intellectual constructs for the reason that in their social embodiment, their individual elements can be adapted to realities, allowing them to obtain qualitatively new phenomena.

It can be argued that the concept of the history of ideas becomes a kind of methodological 
basis for the interpretation of the causes and methods of formation of specific social phenomena that are relevant for each historical era. This approach makes it possible to form a methodology of actions and counteractions, which greatly facilitates the system of interaction between various actors in the modern world.

\section{References}

Afanasyev, V. V. (2014). Sovremennye lokal'nye konflikty (Modern Local Conflicts, in Russian). Moscow State University Bulletin. Series 18. Sociology and Political Science, 1, 142-151.

Badiou, A. (2014). Logiques des mondes. L'Être et l'Événement. Paris Le Seuil.

Berlin, I. (2001). The Power of Ideas. London: Pimlico, Vintage Publishing.

Granovskaya, O. L. (2015). Cennostnyi plyuralizm Isaji Berlina (Isaiah Berlin's Value Pluralism, in Russian). Values and Meanings, 4(38), 15-24.

Gromyko, A. (2020). Koronavirus kak faktor mirovoj politiki (Coronavirus as a Factor in World Politics, in Russian). Scientific and Analytical Herald of Institute of Europe Russian Academy of Sciences, 2(14), 4-13.

Hludneva, S. V. (2003). Artur Lavdzhoi i "Velikaya Cep' Bytiya" (Arthur Lovejoy and "The Great Chain of Being", in Russian). History of Philosophy, 10, 243-251.

Hludneva, S. V. (2005). Ob ocherke Artura Lavdzhoya "Istoriografiya idei" (About the Essay by Arthur Lovejoy "Historiography of Ideas", in Russian). History of Philosophy, 12, 152-157.

Kibardin, A. S., Denisenko, S. Z., \& Saruhanyan,
H. S. (2015). Informacionnaya voina kak osnovnoi sposob dostizheniya voenno-politicheskikh celei $v$ XXI veke (Information War as the Main Way to Achieve Military and Political Goals in the XXI Century, in Russian). Humanities, Social-Economic and Social Sciences, 2(11), 88-91.

Lovejoy, A. O. (1936). The Great Chain of Being. A Study of the History of an Idea. Cambridge, Mass.: Harvard University Press; London: Oxford University Press, Humphrey Milford.

Myunkleg, G. (2003). Voiny XXI veka (Wars of the XXI Century, in Russian). International Journal of the Red Cross, 849$852,7-24$.

Pilyugina, E. V. (2014). Alen Bad'yu: ischislenie sobytiya i protivostoyanie Zhilyu Dele$z u$ (Alain Badiou: Numeration of the Event and His Gilles Deleuze's Opposition, in Russian). Studia Humanitatis, $3,19$.

Radikov, I. V. (2015). Novaya sushchnost' voiny $v$ XXI v. i ee otrazhenie $v$ voennoi doktrine Rossiiskoi Federacii (New Essence of War in the XXI Century and Its Reflection in the Military Doctrine of the Russian Federation, in Russian). Bulletin of St. Petersburg University. Series 6. Political Science. International Relationships, 2, 39-51.

Romanov, B. K. (2020). Koronavirusnaya infekciya COVID-2019 (Coronavirus Disease COVID-2019, in Russian). Safety and Risk of Pharmacotherapy, 8(1), 3-8.

Sadykov, D. I., \& Ahmetyanova, N. A. (2020). Rasprostranenie feikovykh novostei vo vremya pandemii COVID-2019 (Spre- 
ading Fake News During the COVID2019 Pandemic, in Russian). Colloquium Journal, 8(60), 78-79.

Shamsheva, O. V. (2020). Novyi koronavirus Covid-19 (SARS-COV-2) (Novel Coronavirus Covid-19 (SARS-COV-2), in Russian). Children Infections, 19(1), 56.

Shumilin, A. (2020). Faktor pandemii vo vneshnei politike Evrosoyuza (Pandemic Factor in EU Foreign Policy, in Russian). Scientific and Analytical Herald of Institute of Europe Russian Academy of Sciences, 2, 14-21.

Sinchuk, Y. V. (2017). Informacionnye struktury armii vedushchikh zarubezhnykh gosudarstv (Information Structures of the
Armies of Leading Foreign States, in Russian). Vestnik of Moscow State Linguistic University. Social Sciences, 787, 78-94.

Sinchuk, Y. V. (2018). Informacionnaya voina $v$ sovremennykh usloviyakh (Information Warfare in Modern Conditions, in Russian). Greater Eurasia: Development, Security, Cooperation, 189-192.

Zhuravleva, A. S. (2013). Velikaya cep' bytiya. Lavdzhoi o principe izobiliya $v$ filosofii Platona i Leibnica (The Great Chain of Being: From Plato to Leibniz via Lovejoy, in Russian). Bulletin of the Russian Christian Humanitarian Academy, 14(3), 149-156. 